\title{
DHARMAGITA SEBAGAI TERAPI SENI KEAGAMAAN HINDU UNTUK DOSEN DAN MAHASISWA PADA UNIT KEGIATAN MAHASISWA UNIVERSITAS HINDU INDONESIA
}

\author{
Oleh: \\ Ida Ayu Putu Sari \\ iasari@unhi.ac.id \\ Dosen Fakultas Pendidikan, UNHI Denpasar \\ I Ketut Gede Rudita \\ gederudita@unhi.ac.id \\ Dosen Fakultas Pendidikan, UNHI Denpasar
}

\begin{abstract}
ABSTRAK
Dharmagita di dalam pembangunan mental spiritual agama dan meningkatkan pemahaman terhadap nilai-nilai ajaran agama. Untuk mendalami, menghayati dan mengamalkan ajaran dharmagita di lingkungan Universitas Hindu Indonesia diperlukan adanya peranan dosen dan tokoh-tokoh agama dengan memberikan arahan-arahan, bimbingan-bimbingan, sehingga mahasiswa menjadi generasi penerus bangsa yang bermental ideologi Pancasila yang mempunyai keyakinan (sraddha) yang mantap dan tekun melaksanakan ajaran agama. Pembinaan mental ini diperlukan bagi mahasiswa dalam membentuk, memelihara serta meningkatkan kondisi jiwa terhadap agama untuk menumbuh kembangkan sraddha bhakti terhadap Tuhan.
\end{abstract}

Kata Kunci: Dharmagita, Terapi Seni Keagamaan Hindu, Unit Kegiatan Mahasiswa

\begin{abstract}
Dharmagita in the mental spiritual development of religion and increasing understanding of the values of religious teachings. To explore, appreciate and practice the dharmagita teachings within the Hindu University of Indonesia, it is necessary to the role of lecturers and religious leaders by providing direction, guidance, so that students become the next generation of the nation with the mental ideology of Pancasila who have a firm belief (sraddha). and diligently carrying out religious teachings. Mental guidance is needed for students in forming, maintaining and improving the mental condition of religion to foster devotion to God.

Keywords: Dharmagita, Hindu Religious Art Therapy, Student Activity Unit.

\section{PENDAHULUAN}

Konsepsi beragama sering

dikemukakan oleh pemimpin kita baik

formal maupun informal. Pelaksanaan

kehidupan beragama selain memperhatikan kesemarakan juga tentang kedalaman kehidupan beragama (Wiana, 2004:107). Pada tahun enam puluhan
\end{abstract}


seorang peneliti dari AS yang bernama Clifford Geertz yang meneliti berbagai gejala kehidupan beragama di Bali mengatakan bahwa orang-orang Bali yang beragama Hindu sangat sibuk dengan upacara yadnya, namun apa makna upacara yadnya itu kurang di mengertinya (Wiana, 2004:5). Dewasa ini, tingkat kesadaran umat Hindu sudah semakin meningkat, hal ini menandakan kehausan akan ajaran agama Hindu yang mereka mencari tahu dalam buku-buku, bulletin, majalah dan siaran kerohanian semakin banyak bermunculan,hal ini memberikan ciri kebangkitan Hindu kembali (Jendra, 2000: i). Berbicara masalah keimanan, di institusi pendidikan baik ditingkat dasar sampai perguruan tinggi yang memiliki peserta didik yang beragama Hindu diajarkan mengenai ajaran agama Hindu. Ajaran Hindu ini memberi pengaruh terhadap mental bagi generasi muda Hindu.

Salah satu bentuk ajaran agama Hindu yang diberikan di pendidikan formal adalah melalui pemahaman akan budaya yang berdasarkan nilai-nilai keagamaan. Dharmagita merupakan salah satu budaya Hindu yang perlu dikembangkan untuk meningkatkan kualitas kehidupan beragama di kalangan umat Hindu khususnya bagi generasi muda terutama bagi mahasiswa di Universitas Hindu Indonesia. Dilihat dari ragamnya,
Dharmagita terdiri atas : sekar rare, sekar alit, sekar madya, sekar agung (Sukrata,2004:14). Dharmagita sebagai nyanyian keagamaan bagi umat Hindu yang dipergunakan menyertai kegiatan keagamaan khususnya yang berhubungan dengan ritual atau yadnya (Trisdyani, 2019). Penggunaan Dharmagita dalam berbagai kegiatan keagamaan dibutuhkan karena irama lagunya memiliki berbagai jenis variasi yang membantu menciptakan suasana hening, hikmad yang dipancari oleh getaran kesucian sesuai jenis yadnya yang dilaksanakan (Warjana,1996:3). Di Universitas Hindu Indonesia, Unit Kegiatan Mahasiswa (UKM) dharmagita memiliki peminat tersendiri, disamping itu tenaga pendidik (dosen) yang terlibat dalam kegiatan ini juga semakin bertambah dari tahun ke tahun. Akan sangat menarik utnuk dikaji bagaimana pelaksanaan UKM dharmagita ini dilaksanakan dan mampu memberikan semacam terapi kepada para peminatnya di Universitas Hindu Indonesia. Hakekat dari Dharmagita sebagaimana nyanyian suci keagamaan maka unsur estetika (keindahan) merupakan hal yang esensial dalam Dharmagita itu, secara tidak langsung dapat memberikan dan menumbuhkan rasa estetis bagi para pembaca (dosen dan mahasiswa) dan penikmat dari Dharmagita tersebut sehingga menyebabkan mereka menjadi 
terhibur. Apabila pengucapan Dharmagita dilakukan dengan benar dan tepat akan menggetarkan hati nurani yang paling suci, sehingga dapat menguasai pikiran (manah) dan keinginan (indria) yang dikehendakkan dengan baik dapat mengarahkan perbuatan kita berpegang pada Dharma (kebenaran) akan menghasilkan phahala mulia, yakni kehidupan yang bahagia lahir bathin (skala-niskala).

\section{PEMBAHASAN}

\subsection{Profil Universitas Hindu Indonesia}

\section{Denpasar}

Berdirinya Universitas Hindu Indonesia, berawal dari keinginan Para Majelis Agama Hindu membangun atau mengadakan asrama Pangadyayan (Perguruan Tinggi Agama) sebagai tempat untuk mempelajari dharma. Keinginan tersebut terdapat dalam suatu keputusan yang kemudian lebih dikenal dengan nama "Piagam Campuhan Ubud" dan tercetus pada pertemuan yang disebut Dharmacrama yang bertempat di Campuhan Ubud, Kabupaten Gianyar, Bali.

Butir II Piagam Campuhan Ubud inilah yang menjadi titik tolak atau tonggak sejarah pendirian Perguruan Tinggi Agama Hindu dengan nama Maha Widya Bhawana atau Institut Hindu Dharma (IHD). Cita-cita luhur tersebut dapat diwujudkan dua tahun kemudian yaitu pada tanggal 3 Oktober 1963, bertepatan pula dengan hari Purnama Kartika (Purnama Sasih ke 4). Pada hari yang bersejarah ini lahirlah Lembaga Pendidikan Tinggi Agama Hindu yang pertama di bumi Nusantara ini.

Pada awal berdirinya IHD hanya mengasuh dua fakultas yakni Fakultas Agama dan Kebudayaan serta Fakultas Keguruan dan Ilmu Pendidikan Jurusan Biologi. Dibukanya dua fakultas ini sesuai dengan keinginan dan aspirasi yang berkembang ketika itu. Agama dan Kebudayaan merupakan dua aspek yang cukup penting untuk dilestarikan dan dikembangkan sehingga nantinya mampu menunjukkan peran sertanya dalam kancah pembangunan Nasional. Sementara dibukanya Fakultas Keguruan dan Ilmu Pendidikan, khususnya Jurusan Biologi dimaksudkan agar makna Kitab Usada (Ilmu Pengobatan Tradisional) semakin tergali dan dapat disebarluaskan di masyarakat. Semakin tinggi animo masyarakat, menyebabkan pengelola IHD mulai mempertimbangkan untuk membuka fakultas-fakultas baru atau memodifikasi fakultas yang telah ada. Oleh karena itulah dibuka beberapa fakultas lagi guna menampung berbagai aspirasi yang berkembang di masyarakat. Pada akhirnya IHD memiliki empat fakultas masingmasing: Fakultas Ilmu Agama, Fakultas 
Ilmu Pendidikan Agama, Fakultas Hukum Agama, serta Fakultas Sastra dan Filsafat Agama. Dengan empat fakultas ini, IHD semakin dikenal sebagai pengelola Pendidikan Tinggi yang berafiliasi agama Hindu. IHD berhasil melaksanakan Tri Dharma Perguruan Tinggi dengan sukses, baik dalam bidang pengajaran, penelitian, dan pengabdian pada masyarakat. Namun demikian, setelah 30 tahun IHD berdiri, yang merupakan satu-satunya Lembaga Perguruan Tinggi Agama Hindu di Indonesia sampai saat itu belum bisa menghasilkan sepenuhnya para sarjana yang mampu menjawab perubahan dan tantangan zaman pada saat itu. Sehingga mereka banyak yang kalah bersaing dalam pasaran tenaga kerja dengan para sarjana lulusan Perguruan Tinggi lainnya. Hal ini mengakibatkan banyak sarjana IHD menjadi pengangguran.

Hendaknya disadari bahwa, pengelolaan Perguruan Tinggi akan menjadi sulit apabila mahasiswa yang dibina sangat minim. Ide untuk mengembangkan diri secara lebih terbuka dan dapat menampung aspirasi yang lebih bervariasi mulai muncul. Dalam konteks nasional pembangunan dilaksanakan di dalam rangka pembangunan manusia Indonesia seutuhnya dan pembangunan seluruh masyarakat Indonesia. Dalam proses ini maka seluruh lapisan masyarakat termasuk umat Hindu, harus ikut secara aktif dalam perencanaan dan pelaksanaannya.

Usaha-usaha di dalam penguasaan ilmu pengetahuan, teknologi, keterampilan khusus, mutlak diperlukan tentunya tanpa bertentangan dengan nilai-nilai agama Hindu. Melihat hal itu, dan melihat juga latar belakang berdirinya IHD yang semata-mata didorong oleh keinginan luhur dan kurangnya pembinaan terhadap umat Hindu di masa lalu, sudah sepantasnya dirubah bentuknya menjadi Universitas Hindu yang disesuaikan dengan perkembangan ilmu pengetahuan dan tantangan-tantangan yang semakin komplek dewasa ini. Dan dengan dikeluarkannya Surat Keputusan Menteri Pendidikan dan Kebudayaan Republik Indonesia No. 75/D/O/1993 tertanggal 19 Mei 1993, maka secara resmi Universitas Hindu Indonesia (UNHI) berdiri di kota Denpasar.

Unit Kegiatan Mahasiswa (disingkat UKM) adalah wadah aktivitas kemahasiswaan luar kelas untuk mengembangkan minat, bakat dan keahlian tertentu. Lembaga ini merupakan partner organisasi kemahasiswaan intra kampus lainnya seperti senat mahasiswa dan badan eksekutif mahasiswa, baik yang berada di tingkat program studi, jurusan, maupun universitas. Lembaga ini bersifat otonom, dan bukan sebagai cabang dari badan eksekutif maupun senat mahasiswa. 
UKM Dharmagita UNHI Denpasar merupakan suatu organisasi kemahasiswaan yang merupakan wadah bagi mahasiswa dan dosen untuk belajar dan sharing tentang segala hal mengenai dharmagita.

\subsection{Bentuk Pelaksanaan UKM \\ Dharmagita di Universitas Hindu}

\section{Indonesia Denpasar}

Proses pembelajaran adalah proses interaksi antara peserta didik dengan pendidik dan sumber belajar pada suatu lingkungan belajar. Pembelajaran merupakan bantuan yang diberikan pendidik agar dapat terjadi proses pemerolehan ilmu dan pengetahuan, penguasaan kemahiran dan tabiat, serta pembentukan sikap dan kepercayaan pada peserta didik. Dengan kata lain pembelajaran adalah proses untuk peserta didik agar dapat belajar dengan baik. Trianto (2010:17) berpendapat bahwa pembelajaran merupakan aspek kegiatan manusia yang kompleks, yang tidak sepenuhnya dapat dijelaskan. Pembelajaran secara sederhana dapat diartikan sebagai produk interaksi berkelanjutan antara pengembangan dan pengalaman hidup. Pembelajaran dalam makna kompleks adalah usaha sadar dari seorang guru untuk membelajarkan siswanya (mengarahkan interaksi siswa dengan sumber belajar lainnya) dalam rangka mencapai tujuan yang diharapkan. Proses Pelaksanaan UKM Dharmagita di Universitas Hindu Indonesia Denpasar dari dua tahap yaitu : (1) Perencanaan proses kegiatan ekstrakurikuler dharmagita dan (2) Pelaksanaan proses kegiatan ekstrakurikuler dharmagita.

\subsubsection{Perencanaan Proses Kegiatan}

\section{Dharmagita}

Sangat penting bagi seorang pembina UKM untuk melakukan perencanaan proses pelaksanaan kegiatan dharmagita, sebelum pembina tersebut melakukan kegiatan pembelajaran. Rencana proses kegiatan tersebut terdapat beberapa komponen yang harus dibuat oleh pembina yang nantinya dipakai sebagai acuan dalam praktek kegiatan dharmagita, hal ini disampaikan oleh pembina UKM dharmagita :

Sebelum melakukan kegiatan UKM dharmagita, saya biasanya mempersiapkan beberapa hal seperti, menganalisa tingkat kesesuaian materi dharmagita yang diberikan, menganalisa metode yang dipakai dalam praktek dilapangan dan menyusun rencana pelaksanaan kegiatan. Hal ini dilakukan sebagai salah satu upaya agar pembelajaran bisa berjalan dengan efektif. (Bapak Suatama, pembina UKM dharmagita). 
Berdasarkan wawancara tersebut dapat disimpulkan dalam proses kegiatan UKM dharmagita, yaitu dengan mempersiapkan materi ajar dharmagita dan menyusun rencana program kegiatan UKM dharmagita.

\subsubsection{Pelaksanaan Proses Kegiatan}

\section{UKM Dharmagita}

Pelaksanaan proses kegiatan UKM dharmagita di UNHI Denpasar, merupakan kegiatan inti dimana mahasiswa diajarkan melantunkan nyanyian-nyanyian dharma. Adapun pelaksanaannya yaitu melaksanakan kegiatan UKM dharmagita bagi mahasiswa an sesuai rencana pembelajaran yang disampaikan oleh pembina UKM dharmagita sebagai berikut :

1) Tahap I

Tahap awal pelaksanaan dilakukan dalam bentuk kelompok. Mahasiswa yang mengikuti UKM dharmagita adalah seluruh mahasiswa yang terdaftar dalam UMK Dharmagita. Kegiatan UKM dharmagita dilaksanakan setiap hari Sabtu yaitu pada jam muatan lokal yang berlangsung selama 2 jam pelajaran, yang dimulai pada pukul 07.30 sampai 08.40, di bina pembina UKM dharmagita.
Pengelompokan mahasiswa tersebut, berdasarkan atas beberapa pertimbangan yaitu : minat dan bakat mahasiswa, latar belakang kemampuan mahasiswa. Tujuan utama pengelompokan ini adalah untuk mempermudah penyampaian bahan ajar yang diterima peserta didik dan disesuaikan dengan kemampuan.

2) Tahap II

Tahap kedua tim pembina memberikan materi pelajaran atau materi dharmagita yang akan dipelajari, dalam memberikan ru juga sekaligus melakukan praktek dharmagita dengan peserta secara langsung.

3) Tahap III

Pada tahap ketiga setelah memberikan materi dan praktek langsung, guru dan mahasiswa menyimpulkan inti dari materi yang telah dipelajari guna memahami ajaran yang tersirat dalam nyanyian dharmagita tersebut.

4) Tahap IV

Tahap keempat dilakukan penilaian terhadap pemahaman mahasiswa dalam proses kegiatan UKM dharmagita, berupa teori dan praktek.

2.3 Proses Terapi Seni Keagamaan Hindu Yang Dilaksanakan Oleh UKM Dharmagita Universitas Hindu Indonesia 
Kehidupan manusia di era globalisasi nampak sangat jauh dari rasa damai, kemajuan ilmu pengetahuan dan teknologi tampaknya justru lebih banyak membawa pengaruh negatif bagi manusia, menimbulkan pesatnya kemerosotan moral dan etika bagi manusia. Hal ini terjadi karena tidak dibarengi oleh kesadaran dan kasih dalam diri manusia oleh sebab itu diperlukan penanaman nilai pendidikan agama dan budi pekerti sejak dini. Melihat kehidupan beragama dari umat Hindu khususnya umat Hindu yang ada di Bali, kegiatan upacara agama (panca yadnya) tidak terlepas dari Panca Gita sebagai pengiring atau penunjang pelaksanaan yadnya. Panca Gita adalah lima jenis suara atau bunyi yang mengiringi atau menunjang pelaksanaan yadnya yaitu berupa getaran mantram, suara genta, suara kidung atau dharmagita, suara gambelan dan suara kentongan (kulkul). Dharmagita adalah salah satu bagian dari panca gita yaitu berasal dari kata dharma yang berarti agama, kebenaran dan gita berarti nyanyian. Adapun proses terapi seni keagamaan Hindu pada kegiatan UKM dharmagita yang dilakukan oleh mahasiswa dan dosen di UNHI Denpasar merupakan tuntutan dari kurikulum, dan sebagai sarana pembinaan perilaku mahasiswa.
2.3.1 UKM Dharmagita sebagai

\section{Pembinaan Perilaku Mahasiswa}

Penyimpangan etika dan moral dapat menimbulkan pola kehidupan dan pergaulan yang menyimpang. Tidak hanya akibat negatif yang dihasilkan medernisasi dan globalisasi. Proses ini juga menghasilkan akibat positif, yaitu terciptanya masyarakat yang lebih intelek dan melek terhadap perubahan dan perkembangan dunia kearah kemajuan (Shadewo, 2012:1).

Pendidikan etika Hindu yaitu Tri Kaya Parisudha dapat dijadikan pedoman untuk membina umat Hindu agar selalu bersikap dan bertingkah laku yang baik, termasuk selalu berbuat baik kepada siapapun juga. Orang yang telah mendapatkan pendidikan agama Hindu dari kecil dalam lingkungan keluarga, maka secara langsung anak itu sudah memiliki kepribadian dan moral yang kuat yang menjadikan sikap anak tersebut menjadi lebih baik. Peran agama amat penting bagi kehidupan umat manusia, ajaran-ajaran agama ditempuh melalui jejang pendidikan, baik pendidikan di lingkungan keluarga, dunia pendidikan maupun di masyarakat.

Dalam lingkungan pendidikan formal yaitu perguruan tinggi memberikan pendidikan ilmu pengetahuan juga mengajarkan tentang sikap dan tingkah laku yang baik. Membina etika dan moral 
mahasiswa melalui kegiatan kokurikuler dan UKM, UKM yang bergerak khusus pada pendidikan agama Hindu dan sebagai wadah dalam memperkuat mahasiswa dalam memahami etika dan moral yang berlandaskan ajaran agama yaitu agama Hindu.

Untuk mengimbangi perkembangan ilmu pengetahuan dan meningkatkan etika dan moral, UNHI Denpasar menerapkan kegiatan UKM dharmagita, selain kurikulum sebagai alasan yang melatarbelakangi kegiatan UKM dharmagita adapun alasan lainnya yaitu sebagai pembinaan perilaku mahasiswa. Hal ini sesuai dengan apa yang diungkapkan oleh pembina UKM Dharmagita pada UKM Dharmagita UNHI Denpasar, yaitu :

Dalam mengikuti UKM

Dharmagita, mahasiswa mempraktekan tembang-tembang dan secara tidak langsung mahasiswa dapat merasakan dan menghayati isi dan pesan dari tembang tersebut, semakin sering mahasiswa berlatih dharmagita semakin tersentuh hatinya sehingga dalam keseharian mereka akan mengingat pesan yang disampaikan oleh tembang tersebut. (Suatama guru pembina UKM dharmagita)
Perilaku negatif yang ditunjukan mahasiswa disebabkan oleh faktor pemahaman mahasiswa tentang ajaran agama hanya sebatas wacana yang belum bisa dipahami dan dipraktekkan. Berdasarkan fenomena di lapangan perlu adanya suatu tindakan yang berkesinambungan melalui pembinaan perilaku serta pengendalian diri guna menumbuh kembangkan sikap mental yang baik, beretika serta bermoral yang memegang teguh pada ajaran dharma, seperti halnya diungkapkan oleh dosen dharmagita UNHI Denpasar :

Selain tuntutan kurikulum, penanaman etika dan moral melalui UKM dharmagita sangat penting diberikan pada mahasiswa, agar mahasiswa lebih memahami mana perbuatan yang baik dan buruk sesuai ajaran agama, intinya berprilaku baik sehingga mahasiswa dapat memahami, mengamalkan, serta mempraktekkan ajaran tersebut baik dilingkungan sekolah, keluarga maupun di masyarakat. Karena melaui dharmagita atau nyanyian yang dilantunkan dengan pengahayatan lebih mudah untuk mahasiswa memahami dan membina perilaku mahasiswa. (Ibu Surawati pembina UKM dharmagita). 
Berdasarkan hasil wawancara dapat peneliti simpulkan bahwa alasan diterapkannya kegiatan UKM dharmagita mahasiswa UNHI Denpasar yaitu karena tuntutan kurikulum dan sebagai pembinaan perilaku mahasiswa yang diharapkan dapat adalah sebagai wadah dalam menanamkan nilai pendidikan agama Hindu dengan adanya interaksi berupa kegiatan metembang yang merangsang pikiran dan pengendalian diri serta mahasiswa merespon dengan positif kegiatan tersebut sehingga hasil yang diharapkan dapat tercapai berupa perubahan tingkahlaku mahasiswa yang baik.

\subsubsection{Dharmagita sebagai Pembimbing}

\section{Perasaan Menuju Suasana Kesucian}

Dapat dipahami, bahwa sebagai manusia makhluk ciptaan Tuhan dikarunia-Nya alat hidup yaitu jiwa. Inti jiwa adalah atman, atma dibungkus oleh citta ialah triguna seperti sifat satwam, rajas, dan tamas, yang dimiliki oleh setiap manusia. Sifat sattwam ialah non aktif penuh kesabaran, sifat rajas adalah aktif kurang kesadaran, dan sifat tamas adalah pasif, acuh tak acuh. Citta ini merekam hasil-hasil pengamatan panca indria dan sifat-sifat hasil rekaman tergantung dari pada tebal tipisnya ruang gerak ketiga guna tadi mendapat kesempatan lolos kontrolnya sang citta. Panca indria diumpamakan seperti kontrolnya sang citta. Panca indria diumpamakan seperti 5 ekor kuda, bila tidak dikendalikan secara baik dan tepat larinya pun akan tidak seimbang, ketidakseimbangan menyebabkan pertentangan. Apabila sifat sattwam yang berperanan mengendalikan panca indrianya seseorang, maka ia mempunyai kesadaran tinggi meskipun kurang aktivitasnya; apabila rajas yang berperan mengendalikan panca indrianya, maka ia adalah seorang berinisiatif besar, tapi kurang kesadarannya; sedang apabila tamas berperanan mengendalikan panca indrianya, maka ia adalah ingatan dan kenangan yang dihasilkan dari pengalaman-pengalaman rabaan panca indria. Kenangan dan ingatan ini akibat dari rasa atau perasaan keterkaitan kepada benda-benda duniawi tersebut oleh panca indria tadi. Keterikatan panca indria, karena keinginan manusia. Keinginan terikat pada benda-benda duniawi menimbulkan gerak, berbuat atau perbuatan. Perbuatan baik (subha karma) menghasilkan rekaman dalam citta berupa ingatan dan kenangan. Perbuatan yang baik (subha karma) lebih serasi daripada perbuatan yang tidak baik (asubha karma) untuk tidak baik, akan banyak mengakibatkan pertentangan atau ketidakserasian perasaan manusia menjadi bersih. 
Latihan-latihan dan pengabdian, merupakan sikap yang baik membimbing perasaan manusia untuk mendapat suasana tentram, damai, cerah, dan bersih. Kebaktian merupakan sikap pernyataan terima kasih yang manusiawi terhadap kehidupan ini. Cara-cara kebaktian dapat dinyatakan dengan banyak sikap lahir maupun bathin. Sumber hidup adalah Ida Sang Hyang Widhi Wasa; karenanya khususnya umat Hindu dalam usaha selalu berada dalam alamnya sumber hidup tadi, bersikap dengan cara kebaktian atau pengabdian terutama bagi mereka golongan bakta dan karma margin. Sikap nyata adalah suatu persembahan berupa kidung-kidung/nyanyian pujaan kepada Sang Maha Sumber/Yang Maha Kriya. Dengan sifat-sifat kebaktian dan pengabdiannya, diharapkan sumber hidup selalu berkenan bersatu padanya. Dengan demikian pula pengabdian yang sesungguhnya adalah pernyataan kerelaan/keikhlasan setulus-tulusnya untuk mengerjakan kewajiban tanpa diikat oleh motivasi kepentingan pribadi. Dengan sikap-sikap ini dapat dibina dan merupakan bimbingan yang dinilai artinya positif akan perasaan menjadi lapang, tenang, tidak dihantui oleh bayanganbayangan keingin mendapat pujian, sanjungan sehingga kesombongan dan ketekaburan seseorang dapat diredakan. Umat Hindu percaya dengan persembahan bakti dan pengabdian kepada-Nya, maka sari-sari dari kekuatan bakti dan pengabdianlah yang akan diterimanya sebagai anugrah-Nya, karena beliau Sumber Kebaktian dan Sumber Pengabdian.

Bahkti dan Karma marga ini kalau dikatikan dengan ajaran filsafat Wedanta yang dvaita, ternyata ada persamaanpersamaan pandangan yaitu Tuhan dicari di luar diri manusia; atau dengan kata lain memakai sarana-sarana simbolis berupa sajen-sajen, tempat-tempat persembahyangan atau pura, candi dan terutama memakai kidung sebagai pernyataan ungkapan rasa ke-Tuhanan yang sedalam-dalamnya.

Jnana marga yaitu jalan pengetahuan. Tahu (widya) amat baik membimbing perasaan menjadi bersih. Tahu, mengetahui dengan pengetahuan sama jelas atau terang. Tidak tahu sama dengan buta atau gelap, dan telah dijabarkan pula bahwa "mengetahui" itu melalui proses Tri pramana. Manusia mengetahui dengan alat yang dimilikinya yaitu rasa dan pikiran. Dengan rasa penggeraknya adalah alam intuitif, dengan pikiran penggeraknya panca indria.

Raja marga yaitu jalan latihan konsentrasi atau pemusatan dengan mengendalikan panca indria semaksimalmaksimalnya. Pemusatan perhatian ialah untuk tidak liarnya jiwa ini. Liarnya 
perhatian, memecah kekuatan dan energi pada manusia sendiri. Dan juga pemusatan cara yang benar dalam hubungan ini dengan cara-cara yoga, mengandung pula efek pembersihan kotoran-kotoran yang menganggu jiwa itu. Jiwa yang bersih adalah pembimbing perasaan menuju suasana kesucian. Jiwa yang kotor menghalangi perasaan menuju kesucian.

Catur marga benar-benar dapat menjamin latihan-latihan menuju kebersihan jiwa manusia apabila melaksanakan ajarannya sesuai dengan swadarma masing-masing individu manusia itu sendiri, terutama apabila ia dengan kesungguhannya mengekspresikan jiwanya dalam kebaktian, pengabdian, pengertian, dan pemusatan laksananya sehari-hari.

Akhirnya peranan kidung dalam upacara agama Hindu, bukan sekedar sebagai sarana penunjang menciptakan suasana khidmad, megah, agung, dan suci, tetapi lebih dari itu ialah sebagai transformator, mentransfer pernyataan kebaktian umatnya kehadapan Ida Sang Hyang Widhi Wasa (Ardiyasa, 2019). Pernyataan dengan kata-kata diucapkan dalam bentuk yang ditembangkan atau dinyanyikan, akhirnya kidung dalam upacara Agama Hindu kiranya dapat dinyatakan tidak lain daripada bahasa kebaktian dalam cara penyampaian kesujudan kepada Tuhan Yang Maha Esa.

\subsection{Dampak Yang Dirasakan Dalam}

Mengikuti Kegiatan UKM

Dharmagita Universitas Hindu

\section{Indonesia}

\subsubsection{Dharmagita sebagai Pencurahan} Perasaan Bhakti

Dalam srada Agama Hindu diakui bahwa manusia terjadi dari dua unsur pokok yaitu badan wadag dan jiwa. Hukum Rwa Bhineda yaitu pandangan dua dimensi dalam kesatuan berlaku pula atas manusia. Jiwa manusia dapat berwujud kehendak, akal dan emosi. Ketiga sifat jiwa itu diwujudkan oleh faktor ekspresi yang sangat memegang peranan penting. Dalam manusia mencapai tujuannya, unsur jiwa sangat memegang peranan, termasuk dalam tujuan manusia menuju Tuhan-Nya. Usahanya akan hidup, tidak dimanfaatkan sebaik-baiknya. Sedangkan unsur badan wadag, merupakan pendukung kegiatan yang dilakukan jiwa. Dalam proses manusia menuju Tuhan, dimulailah kegiatan jiwanya dengan sikap kehendak, kemauan atau keinginan. Dan dalam melaksanakan ini manusia mencari cara dengan berbagai jalan dalam bentukbentuk yang dipolakan. Pada tingkat pemecahan masalah mendapatkan cara atau jalan, manusia mengadakan usahausaha. Untuk menentukan usaha mereka memerlukan pemikiran, akal. Pikiranpikiran logis segera dapat dihasilkan । 36 
ekspresi akal tadi, yang akan digunakan manusia dalam melaksanakan kehendaknya menuju Tuhan, maka lahirlah ekspresi emosi dari jiwanya (emosi diidentikkan dengan perasaan). Ekspresi emosi jiwa manusia inilah yang paling dominan peranannya dalam hubungannya menjiwai kidung-kidung sebagai nyanyian pujaan kepada Tuhan. Pada dasarnya wujud perasaan yang merupakan salah satu sikap jiwa manusia, adalah bersifat universal, dimiliki oleh setiap insan/manusia. Umumnya sikap ekspresi perasaannya mengarah kepada dua dimensi dalam kesatuannya (Rwa bhineda) ialah yang bersifat positif dan negatif yang sangat besar ditentukan Tri Guna pada setiap individu manusia sendiri. Sikap ekspresi yang positif dan negatif, kiranya dapat disebut dalam istilah kerohanian agak lembut, adalah sebagai bersifat kedewataan dan keraksasaan. Sifat kedewataan adalah positif dan keraksasaan yang negatif.

Sujud bakti, cinta kasih dan semua sikap ekspresi yang sejenis dengan itu berada dalam perasaan alam kedewataan statusnya pun lebih tinggi dari alamnya perasaan keraksasaan. Karena alam kedewataan itu merupakan sinar kekuatan Ida Sang Hyang Widhi, dan apabila perasaan itu dilatih ke arah kedewataan, berarti juga melatih perasaan ke alam Tuhan.
Jadi tampaklah di sini penanan Dharmagita dalam pendidikan agama Hindu, bahwa melalui pengucapanpengucapan lagu-lagu keagamaan itu ekspresi emosi akan terlatih mencapai alam kedewataan dan apabila betul-betul dilaksanakan bahwa Dharmagita sebagai pencurahan rasa bhakti kepada Ida Sang Hyang Widhi Wasa. Emosi yang kuat dari pada penyanyi Dharmagita adalah dibhaktikan untuk suatu upacara yang dilaksanakan, pencurahan semua emosi kedewataan yang dibadani oleh ucapanucapan Dharmagita atau kekidung dan setiap kata dari kidung itu dihidupkan dengan ekspresi emosinya, maka getaran kidung mengantar menuju alam kedewataan, menyentuh kekuatan Ida Sang Hyang Widhi, maka terjadilah kesatuan dari dua kekuatan suci yang satu dari umatnya melalui Dharmagita dan satu lagi dari sumber kekuatan itu yaitu Tuhan itu sendiri. Di sinilah latar belakang arti pencurahan, dan pertemuan ini merupakan alam kedamaian. Sikap-sikap ekspresi perasaan yang positif seperti di atas, yakni : sujud, bakti, kagum, tenang, bahagia, damai, dan yang lain semacam itu sulit sekali digambarkan secara nyata kecuali dirasakan. Bila diiringi geguritan atau Dharmagita, kita bisa rasakan indahnya suasana upacara. Tembang laras selendro, diiringi oleh suara gender wayang atau angklung, tembang laras pelog diiringi 
oleh suara gamelan gong, suara penyanyi Dharmagita yang indah dan merdu diiringi oleh gong semara pagulingan dan lain-lain lagi. Semua itu menimbulkan rasa terharu. Apabila upacara yadnya di suatu tempat suci lengkap dengan sarana yadnya, sehingga tergabung 5 suara yakni suara kidung sayup-sayup disertai lelambatan gong yang indah, suara genta dan weda mantra sang pendeta serta suara kulkul silih berganti, tak terlupakan bau dupa dan menyan yang harum, kejadian seperti inilah kalau dinikmati oleh ekspresi emosi sehingga menjadi terharu, bangga, tenang, damai, dan lain-lainnya.

Jadi kalau disimpulkan peranan Dharmagita sebagai pencurahan rasa bhakti ialah dengan sarana oleh vokal atau lagu-lagu keagamaan yang diucapkan dengan penuh rasa sujud bakti dan pasrah kita menemukan alam kedewataan berupa ketenangan, kedamaian, kebahagiaan dan yang lain semacam itu. Memang sangat sulit digambarkan wujud rasa bhakti kecuali dilaksanakan dalam sikap ekspresi.

\subsubsection{Dharmagita sebagai Alat Pranayama}

Dalam hal ini diuraikan salah satu Dharmagita yaitu kekidung, yang lebih menonjol dilagukan dalam pelaksanaan yadnya. Irama kidung yang panjang- panjang dan memerlukan tempo yang lama itu membutuhkan pengaturan napas yang cermat. Kalau pengaturan napas kurang tepat, irama nyanyian kidung akan menjadi suatu penyajian yang putus-putus di tengah-tengah tembang, dan tidak akan mencapi tujuan semestinya. Untuk dapat melakukan pengaturan napas secara baik, maka para penyanyi kidung hendaknya menyelaraskan napas yang ke luar dan napas yang masuk. Sebanyak napas yang ke luar untuk menggetarkan ucapanucapan kata dari kidung itu, sebanyak itu pula napas yang diperlukan (masuk) ke rongga dada. Dalam hubungan ini paruparu secara penuh dan sempat mekar seluruhnya. Dengan mengembangnya paru-paru secara penuh dan juga mengempis secara penuh, maka peredaran darah dalam tubuh si penyanyi akan menjadi lancar pula, mengakibatkan keseimbangan tubuh menjadi normal. Keseimbangan tubuh dalam keadaan normal, maka kesehatannya tertu terjamin, daya tahan tubuhnya semakin kuat dan penyakit pun sukar menyerangnya.

Inilah efek kesehatan yang langsung diterima oleh para penyanyi kidung, jika mereka benar-benar melaksanakan aturan-aturan yang semestinya dalam kekidung.

Seirama dengan irama getaran semesta alam, maka getaran ucapan katakata kidung melalui suara-suara para 
penyanyi menggetarkan juga udara sekitarnya, getaran mana adalah getaran kesucian. Karena para penyanyi menghidupkannya dengan ekspresi kesuciannya, justru karena dihaturkannya kepada yang maha suci. Kekuatan magis dari kidung-kidung itu mempengaruhi partikel-partikel prana bergetar dan dapat menghubungkan gelombang kesuciannya. Di sinilah hubungan itu semestinya dipahami, rasa cinta kasih yang bulat dari umatnya diabadikan sebagai kebaktian berupa wujud kidung, cinta kasih mana juga bersentuhan dengan cinta kasih-Nya, maka secara moral alam semesta telah ikut dipelihara memakai cinta kasih oleh umat Hindu khususnya.

Demikianlah kidung-kidung itu sebagai alat pranayama dapat dimanfaatkan sebaik-baiknya untuk memelihara dunia semesta alam dan sebagai media kesehatan manusia (Suadnyana, 2019). Di sinilah rahasia ini tersembunyi dan pengaturan napas, memanfaatkan napas, mengolah napas atau disebut penguasaan napas atau pranayama, sesungguhnya merupakan iramanya kidung-kidung di Bali; sebaliknya dengan gaya menyanyi kidung-kidung di Bali secara langsung adalah latihan pengolahan pernapasan yang mempunyai efek sangat besar terhadap kesehatan para penyanyi dan pemeliharaan keseimbangan tubuh manusia.
Karakter penataan kidung yang memakai irama panjang-panjang tidak lain dibutuhkan untuk mengekspresikan dorongan-dorongan emosi kerinduan, cinta kasih, dan sendu (Prawira, 2019). Untuk dapat membawakan irama yang panjangpanjang sesuai semestinya penyajian kidung-kidung itu oleh seorang penyanyi kidung sebaiknya pandai mengatur napasnya. Mengatur napas secara baik dimaksudkan cara menarik (memasukkan) napas, menyimpan (menahan) napas, dan menghembuskannya pada saat diperlukan dalam pengolahan irama kidung-kidung itu.

Masalah lain harus diungkapkan di sini, yaitu mengapakah irama kidungkidung itu kebanyakan panjang-panjang? Seperti diketahui angkasa ini penuh dengan getaran-getaran dan gelombanggelombang yang tiada hentinya bergerak secara aturan hukum alam. Materi pokok kidung-kidung itu ialah suara. Suara dapat didengar apabila getaran per detik/frekuensinya dapat beresonansi dengan medium getaran, kemudian medium ini mengantarkan resonansi melanjutkan kepada objek penerimanya. Si penerima baru menerima getaran tadi dan baru tahu setelah mendengar suara itu. Ilmu alam tentang getaran, rupanya sudah dipelajari oleh para yogi, para maha rsi di zaman dahulu. Kalau tidak, tidak mungkin yoga itu mengajarkan pernapasan dan cara 
bernapas yang benar, dalam usaha mendapatkan gelombang-gelombang getaran kekuatan alam semesta ini selalu bergetar dan untuk suatu keseimbangan maka amatlah penting bergetarnya seluruh sel pada tubuh manusia ini seimbang pula dengan hukum getaran alam semesta (ikut bergetar/beresonansi). Ikut bergetar/beresonansi ini rupanya menjadi dasar-dasar pengetahuan pranayama dari mana prana dapat dimanfaatkan ke tubuh manusia secara tepat. Dan untuk bergetar (resonan) secara spiritual, maka yang paling efisien yang digunakan manusia adalah suaranya sendiri. Dengan suaranya sendiri ingin menggetarkan medium tadi (angkasa), yang melanjutkan kepada objek tujuannya. Untuk tidak putus-putusnya getar medium itu, maka suarapun dipanjang-panjangkan atau suara kidungkidung itu sendiri. Inilah kiranya tujuan dari pada penataan kidung-kidung di Bali iramanya sengaja dilakukan panjangpanjang. Dengan memenuhi kebutuhan akan irama panjang-panjang dalam penyajian kidung itu tentu dibutuhkan pengaturan napas yang secermatcermatnya. Pengaturan napas dalam penyajian kidung-kidung itu sangatlah pasti. Membiasakan pernapasan panjangpanjang, diperlukan latihan-latihan yang benar.

\section{III.PENUTUP}

Dharmagita merupakan salah satu budaya Hindu yang perlu dikembangkan untuk meningkatkan kualitas kehidupan beragama di kalangan umat Hindu khususnya bagi generasi muda terutama bagi anak-anak pelajar. Dharmagita terdiri atas : sekar rare, sekar alit, sekar madya, sekar agung. Dharmagita sebagai nyanyian keagamaan bagi umat Hindu yang dipergunakan menyertai kegiatan keagamaan khususnya yang berhubungan dengan ritual atau yadnya. Dharmagita merupakan salah satu media kesenian yang sangat menunjang dalam pemahaman diri dan meningkatkan kesadaran rohani. Hendaknya pembinaan kehidupan rohani dilakukan dengan mengembangkan serta memanfaatkan kesenian di masing-masing daerah, agar masyarakat lebih semarak dalam memahami dirinya. Dharmagita diartikan sebagai sebagai suatu seni keagamaan hindu di dalamnya terdapat syair-syair yang sudah diringkas sedemikian rupa dan penuh dengan ajaran keagamaan kemudian dilantunkan dengan suara yang amat memesona. Melalui Dharmagita seseorang dapat menghayati ajaran agama secara mendalam sehingga perasaan pikiran dan budhinya menjadi halus. Lagu-lagu keagamaan yang dinyanyikan dalam Dharmagita dapat menggetarkan alam rasa dan meningkatkan sraddha bhakti kepada 
SangHyang Widhi Wasa. Dengan

Dharmagita seseorang akan dapat mengendalikan diri dari pengaruh adharma.

\section{DAFTAR RUJUKAN}

Ardiyasa, I. Nyoman Suka, and Ida Bagus Putu Eka Suadnyana. "MITIGASI TEOLOGIS BENCANA ALAM DALAM NASKAH LONTAR ROGA SANGHARA BHUMI." Genta Hredaya 1.1 (2019).

Jendra, 2000, Metode Dharma Wacana dan Etika Berbicara, Denpasar, BP.

Manson Mark, 2018, Sebuah Seni Untuk Bersikap Bodo Amat, Jakarta,PT Gramedia

Mastini, Ni Wayan (2013) Penelitian "Peranan Dharmagita Dalam Meningkatkan Kreativitas Siswa di SD No. 1 Singapadu Kaler Sukawati Gianyar". Universitas Hindu Indonesia.

NI NYOMAN TANJUNG TURAENI: BENTUK, FUNGSI, DAN MAKNA TRADISI LISAN. Jurnal METASASTRA, Vol. 4 No. 2, Desember 2011: 171-180

Prawira, I. Made Agus Adi, and Ida Bagus Putu Eka Suadnyana. "FENOMENA NGIRING PADA MASYARAKAT HINDU DI BALI." Genta Hredaya 2.2 (2019).
Putra, I Made (2013) dalam penelitian "Dharmagita sebagai media pembelajaran agama Hindu pada siswa di SD Negeri 1 Penebel, Kecamatan Penebel, Kabupaten Tabanan". Universitas Hindu Indonesia.

Suadnyana, Ida Bagus Putu Eka. "AJARAN AGAMA HINDU DALAM GEGURITAN KUNJARAKARNA." Genta Hredaya 3.1 (2019).

Sudirga, Ida Bagus (2017) Peranan Dharmagita Dalam Meningkatkan Sradha Dan Bhakti Siswa Hindu. Vidya Samhita Jurnal Penelitian Agama, III (1) 2017 p-ISSN: 24603376, e-ISSN: 2460-4445

Suarka, I Nyoman. 2007. Kidung Tantri Pisacarana. Denpasar: Pustaka Larasan

Sukarta, 2004. Dharmagita Agama Hindu. Ganeca Exact, Denpasar.

Surada, I Made. 2006. Dharmagita: Kidung Panca Yajña, Beberapa Wirama, Sloka, Phalawakya, dan Macepat. Surabaya: Paramita

Trisdyani, Ni Luh Putu, and Ida Bagus Putu Eka Suadnyana. "ETIKA HINDU DALAM CERITA TANTRI KAMANDAKA." Jñānasiddhânta 1. 1 (2019).

Wiana, I Ketut Drs.2004. Yadnya dan Bhakti di Tinjau Dari Sudut Pandang Hindu. Pustaka Manik Geni. 